\title{
Organomineral nanocomposite carbon burial during Oceanic Anoxic Event 2
}

\author{
S. C. Löhr and M. J. Kennedy \\ Sprigg Geobiology Centre, School of Earth and Environmental Science, University of Adelaide, Adelaide 5005, Australia \\ Correspondence to: S. C. Löhr (stefan.loehr@adelaide.edu.au)
}

Received: 11 March 2014 - Published in Biogeosciences Discuss.: 12 May 2014

Revised: 18 August 2014 - Accepted: 21 August 2014 - Published: 18 September 2014

\begin{abstract}
Organic carbon (OC) enrichment in sediments deposited during Oceanic Anoxic Events (OAEs) is commonly attributed to elevated productivity and marine anoxia. We find that $\mathrm{OC}$ enrichment in the late Cenomanian aged OAE 2 at the Demerara Rise was controlled by the co-occurrence of anoxic bottom water, sufficient productivity to saturate available mineral surfaces, and variable deposition of high surface area detrital smectite clay. Redox indicators show consistently oxygen-depleted conditions, while a strong correlation between OC concentration and sediment mineral surface area $\left(R^{2}=0.92\right)$ occurs across a range of total organic carbon (TOC) values from 9 to $33 \%$. X-ray diffraction data indicate the intercalation of OC in smectite interlayers, while electron, synchrotron infrared and X-ray microscopy show an intimate association between clay minerals and OC, consistent with preservation of $\mathrm{OC}$ as organomineral nanocomposites and aggregates rather than discrete, $\mu \mathrm{m}$-scale pelagic detritus. Since the consistent ratio between TOC and mineral surface area suggests that excess OC relative to surface area is lost, we propose that it is the varying supply of smectite that best explains variable organic enrichment against a backdrop of continuous anoxia, which is conducive to generally high TOC during OAE 2 at the Demerara Rise. Smectitic clays are unique in their ability to form stable organomineral nanocomposites and aggregates that preserve organic matter, and are common weathering products of continental volcanic deposits. An increased flux of smectite coinciding with high carbon burial is consistent with evidence for widespread volcanism during OAE 2, so that organomineral carbon burial may represent a potential feedback to volcanic degassing of $\mathrm{CO}_{2}$.
\end{abstract}

\section{Introduction}

The geological record is punctuated by intervals of widespread organic carbon (OC) enrichment known as Oceanic Anoxic Events (OAEs) (Arthur and Sageman, 1994; Jenkyns, 2010; Schlanger and Jenkyns, 1976). The latest Cenomanian aged OAE 2 (Cenomanian/Turonian boundary $\approx 93.9 \mathrm{Myr}$ ago) is considered the best developed and most widespread OC-enriched interval interpreted as resulting from an OAE, as it shows evidence of deep-water anoxia as well as a general continuity of black shale deposition across the Atlantic and Tethyan basins (Arthur et al., 1987). A positive $\delta^{13} \mathrm{C}$ excursion in bulk organic matter (up to $7 \%$ ) and carbonates (2-3\%o) implies that global OC burial increased by $130 \%$ during this period (Arthur et al., 1988; Erbacher et al., 2005), and was accompanied by a selective extinction event that most severely affected benthic organisms and has been attributed to deep-water oxygen depletion (Kaiho and Hasegawa, 1994). OAE 2 also coincides with greenhouse conditions, including high atmospheric $p \mathrm{CO}_{2}$ (Bice and Norris, 2002; van Bentum et al., 2012), low oxygen conditions in a warm ocean (Friedrich et al., 2012) and a period of intensified volcanism (Sinton and Duncan, 1997; Turgeon and Creaser, 2008) which may have triggered expansion of anoxia through release of hydrothermal fluids (Orth et al., 1993; Sinton and Duncan, 1997) and stimulation of primary productivity (Adams et al., 2010).

Organic enrichment in marine sediments during OAEs shows a complex mixture of influences (Arthur and Sageman, 1994; Kuypers et al., 2004), but is most commonly attributed to bottom-water anoxia and/or increased primary productivity (e.g. Arthur and Sageman, 1994; Mort et al., 2007). A basin-wide tendency toward OC enrichment is modulated by local continental influences that 
dominate particular records (Beckmann et al., 2005), raising the fundamental question of whether additional mechanisms are required for OC concentration. Continental effects may be indirectly expressed through oceanographic processes such as enhanced freshwater run-off causing stratification (Beckmann et al., 2005) and/or nutrient delivery (Pratt, 1984); however, recent studies of modern and ancient continental margin sediments identify an additional influence via the OC preservation effects of detrital mineral surfaces (Keil and Cowie, 1999; Kennedy and Wagner, 2011; Mayer, 1994). This work showed that organic matter of marine origin is stabilised through association with terrestrially derived clay minerals, in particular high surface area smectitic clays. Mineral surface association stabilisation is particularly effective where it occurs in association with anoxia, because anoxia supports high dissolved OC, excludes bioturbators, and reduces oxidant exposure time (Blair and Aller, 2012; Hedges et al., 1999; Keil and Cowie, 1999; Kennedy and Wagner, 2011).

The general importance of mineral surfaces is yet to be determined, but is pertinent because concentrations resulting from their effects have very different implications for the origin of organic-rich rocks than purely oceanographic mechanisms. Reactive, high surface area detrital clay minerals such as smectite form in soils and by weathering of volcanic rocks (Chamley, 1989), so they represent a continental influence. However, since most smectite forms under sub-tropical, seasonally contrasted conditions and is subsequently eroded and transported to continental margins by rivers, this implies a spatially constrained distribution limited by zonal climate (Chamley, 1989). Thus, the potential influence of smectite on the basinal scale OC enrichment evident during OAE 2 (Takashima et al., 2006) remains unclear.

Here we look at a deep marine section that is persistently oxygen depleted through the OAE 2 interval, yet shows large variation in total organic carbon (TOC). We test whether variable $\mathrm{OC}$ enrichment is the result of a fluctuating supply of detrital clays with a preservative effect on OC, combining the characterisation of bulk sediment properties with high-resolution, electron microscope and synchrotron-based imaging of organic matter distribution and its association with clay minerals. We further consider potential mechanisms that could result in a basin-scale clay mineral influence on carbon burial.

\section{Study materials}

A thick sequence (> $80 \mathrm{~m}$ ) of organic-rich sediments representative of the equatorial North Atlantic margin, including OAE 2, was recovered during Ocean Drilling Program (ODP) Leg 207 at the Demerara Rise. High hydrogen indices (mostly greater than $500 \mathrm{mg} \mathrm{HC} / \mathrm{g} \mathrm{OC}$ ), RockEval $T_{\max }$ less than $400^{\circ} \mathrm{C}$, and the dominance of hopanes and steranes retaining their biological structural configurations suggest that the bulk of the organic matter $(\mathrm{OM})$ in these sequences is marine in origin and thermally immature (Forster et al., 2004; Meyers et al., 2006), so that we expect the original OCmineral associations established within the depositional environment to be retained (Kennedy et al., 2014). We collected and analysed a total of 120 samples at $10 \mathrm{~cm}$ spacing from ODP sites 1258, 1260 and 1261, across the positive $\delta^{13} \mathrm{C}$ excursion interpreted as marking the onset of OAE 2 (Erbacher et al., 2005).

\section{Methods}

All samples for bulk analysis were ground in an agate mortar and pestle to pass through a $200 \mu \mathrm{m}$ sieve. Subsamples for sediment mineral surface area (MSA) determination were shaken in $1 \mathrm{M} \mathrm{CaCl}_{2}$ for $1 \mathrm{~h}$, triple rinsed in deionised water and oven dried $\left(110^{\circ} \mathrm{C}\right.$ for $\left.48 \mathrm{~h}\right)$. MSA measurements were determined using ethylene glycol monoethyl ether (EGME), following the "free surface" procedure of Tiller and Smith (1990), using a factor of 3.2 to convert the mass of adsorbed EGME (mg) to mineral surface area $\left(\mathrm{m}^{2}\right)$, based on an assumption of monolayer coverage (Kennedy and Wagner, 2011). MSA was adjusted for $\mathrm{CaCO}_{3}$ and OC content, and is reported here as "silicate MSA". Six replicates of a suite of clay mineral standards obtained from the Clay Minerals Society and included in the same batch as the samples showed excellent reproducibility (SWy2: $743 \mathrm{~m}^{2} \mathrm{~g}^{-1} \pm 0.52 \%$; STx-1b: $791 \mathrm{~m}^{2} \mathrm{~g}^{-1} \pm 0.29 \%$; IMt2: $104 \mathrm{~m}^{2} \mathrm{~g}^{-1} \pm 2.57 \%$ ).

Total carbon was determined with a LECO Truespec CHN analyser. Inorganic $\mathrm{C}$ was determined using the pressure calcimeter method of Sherrod et al. (2002). Organic C was calculated as the difference between total $\mathrm{C}$ and inorganic $\mathrm{C}$, and is reported on a carbonate-free basis to account for the effects of carbonate dilution. Major and trace element chemistry of Site 1261 samples was determined using standard Xray fluorescence methods (Philips PW 1480 XRF) on fused disks and pressed pellets, respectively.

Sample mineralogy was determined by X-ray diffraction (Bruker D8 Advance X-ray diffractometer with a Cu source) on micronised powders (including a $10 \% \mathrm{ZnO}$ internal standard). The clay mineralogy of the samples was determined on Ca-saturated oriented preparations of the $<2 \mu \mathrm{m}$ fraction (air dried and after treatment with ethylene glycol). The $<2 \mu \mathrm{m}$ fraction was obtained by centrifugation after carbonate removal with $1 \mathrm{M}$ sodium acetate buffer at $\mathrm{pH} 5$ and $90^{\circ} \mathrm{C}$, $\mathrm{OM}$ removal with $\mathrm{NaOCl}$ at $\mathrm{pH} 9.5$ and $90^{\circ} \mathrm{C}$, and ultrasonic dispersal. To test for OM intercalation in the smectite interlayer, the $<2 \mu \mathrm{m}$ fraction of selected samples was also obtained without chemically pretreating the samples. These samples were air dried and analysed as above. They were then reanalysed after heating for 24 hours at temperatures of $105,200,300$ and $400^{\circ} \mathrm{C}$, following the procedure of Theng et al. (1986). 
The micro- to nano-scale distribution and association of clay minerals and OC was determined on (a) ion-polished samples by scanning electron microscopy (SEM) backscatter electron (BSE) imaging and energy dispersive X-ray analysis, and (b) cryomicrotomed, $300 \mathrm{~nm}$ thick ultra-thin sections by imaging these at the infrared microscope (FTIR) beamline of the Australian Synchrotron and the scanning transmission X-ray microscope (STXM) beamline of the Swiss Light Source. A more detailed description of the electronand synchrotron-based imaging methods, including sample preparation, is given in Appendices A to D.

\section{Results and discussion}

Our results identify a strong, positive relationship between sediment MSA and TOC at all three sites (Figs. 1 and 2), both prior to and within the OAE 2 interval, where MSA accounts for 87 to $92 \%$ of the variation in the TOC content of the samples across a range in TOC from 8.9 to $33.4 \%$ of the noncarbonate portion of the sediment. Since we present data for the carbonate-free fraction, we can discount the possibility that the correlation between MSA and TOC is due to changes in the relative abundance of carbonate. Quartz and biogenic opal are other potentially abundant sediment components, but the absence of a negative correlation between the Alnormalised concentrations of OC and Si (Fig. 4) demonstrates that varying dilution by quartz or biogenic silica is not a significant influence on sediment TOC. These finely laminated sediments were deposited from suspension as pelagic or hemipelagic deposits and do not show evidence of current winnowing or concentration such as erosional scours or traction. We thus attribute abrupt changes in MSA to changes in the supply of high MSA phases such as smectite clay from the terrestrial source region. MSA tracks abrupt, highamplitude shifts of TOC (up to $17 \%$ ) between successive samples where the mineralogy of the sediment reflects a primary depositional relation (Fig. 1). Furthermore, trends in MSA do not lead or lag TOC, as might be expected if changes in these indices were indirectly related through a shared environmental control; the proportional sample-to-sample shifts strongly support a direct mechanistic relationship between OC and MSA, implying preservation of sub-micron-scale OC closely associated with clay mineral surfaces, which provide the bulk of sediment MSA (Keil and Mayer, 2014; Kennedy and Wagner, 2011; Ransom et al., 1998). This is consistent with the OC preservation effects of detrital (soilderived) mineral surfaces in modern marine sediments (Blair and Aller, 2012; Keil and Mayer, 2014).

Sediments in modern continental margin settings show two distinct components of OC: discrete organic particles larger than $1 \mu \mathrm{m}$ and a mineral-associated component that cannot be separated by physical means (Keil et al., 1994b). The mineral-associated phase is considerably more refractory (Keil et al., 1994a), and remains relatively constant through the sediment profile. Quantification of the discrete OC phase (Keil et al., 1994b) and comparison of OC-to-MSA ratios (Mayer, 1994) show that, while discrete OM (particles) is commonly dominant at the sediment-water interface, it generally comprises less than $10 \%$ of OC by $30 \mathrm{~cm}$ of the sediment profile. The refractory properties of the mineralassociated fraction make it a more likely component to survive the seafloor diagenetic reactions and enter the geologic record. While a correlation between MSA and TOC has been documented in the few examples of black shale where this relation has been studied (Kennedy and Wagner, 2011; Kennedy et al., 2014, 2002), previous work has relied mainly on bulk sample characterisation rather than direct assessment of clay-organic associations.

Direct imaging of the distribution of OC and its association with mineral surfaces provides an ultimate test to discriminate this sub- $\mu \mathrm{m}$ organomineral style of preservation from preservation of the discrete, micron-sized organic detritus of pelagic origin that is typically considered to constitute the organic fraction (Tyson, 1995). SEM BSE imaging of ion-polished samples demonstrates that OC is widely distributed through the sediment, where it is typically associated with and coats clay minerals, forming organoclay aggregates (Fig. 5), as in modern sediments (Blair and Aller, 2012; Keil and Mayer, 2014). Although individual aggregates can have the appearance of discrete OM particles (Fig. 5a), energy dispersive X-ray analysis (Fig. 5d) and closer inspection at higher magnifications (Fig. $5 b$ and c) reveals the composite clay-organic nature of these zones. Synchrotron Fourier transform infrared (FTIR) and scanning transmission X-ray (STXM) microspectroscopy of multiple cryomicrotomed ultra-thin sections of seven samples, selected across a range of TOC and MSA values, independently confirms that OC and clay minerals have overlapping distributions and are disseminated throughout the sediment, where they are spatially associated (Fig. 6).

A limitation of the small, $\mu$ m-scale field of view of the high-resolution images is that establishing that any given image is representative of the primary form of OC is problematic, so that we offer this type of data only as a proof of concept, while relying on the bulk rock relations (MSA-TOC) to identify the extent of the organo-clay relationship. Thus, our assessment of the relative abundance of clay-associated vs. discrete OM is based on the strong bulk sample relationship between MSA and TOC, which implies that the great majority of OM is associated with clay minerals, and that the OM is sufficiently small to interact and associate meaningfully with clays (Keil and Mayer, 2014; Kennedy et al., 2014; Mayer, 1994). Not only is discrete OM detritus too large to interact meaningfully with the clay mineral matrix, if particulate OC from pelagic sources (and unrelated to mineral surfaceassociated OC) were an important contributor to some of the samples, these would plot above the regression evident in Fig. 2 (high TOC with limited surface area), indicating the presence of OC that was independent and unrelated to the 

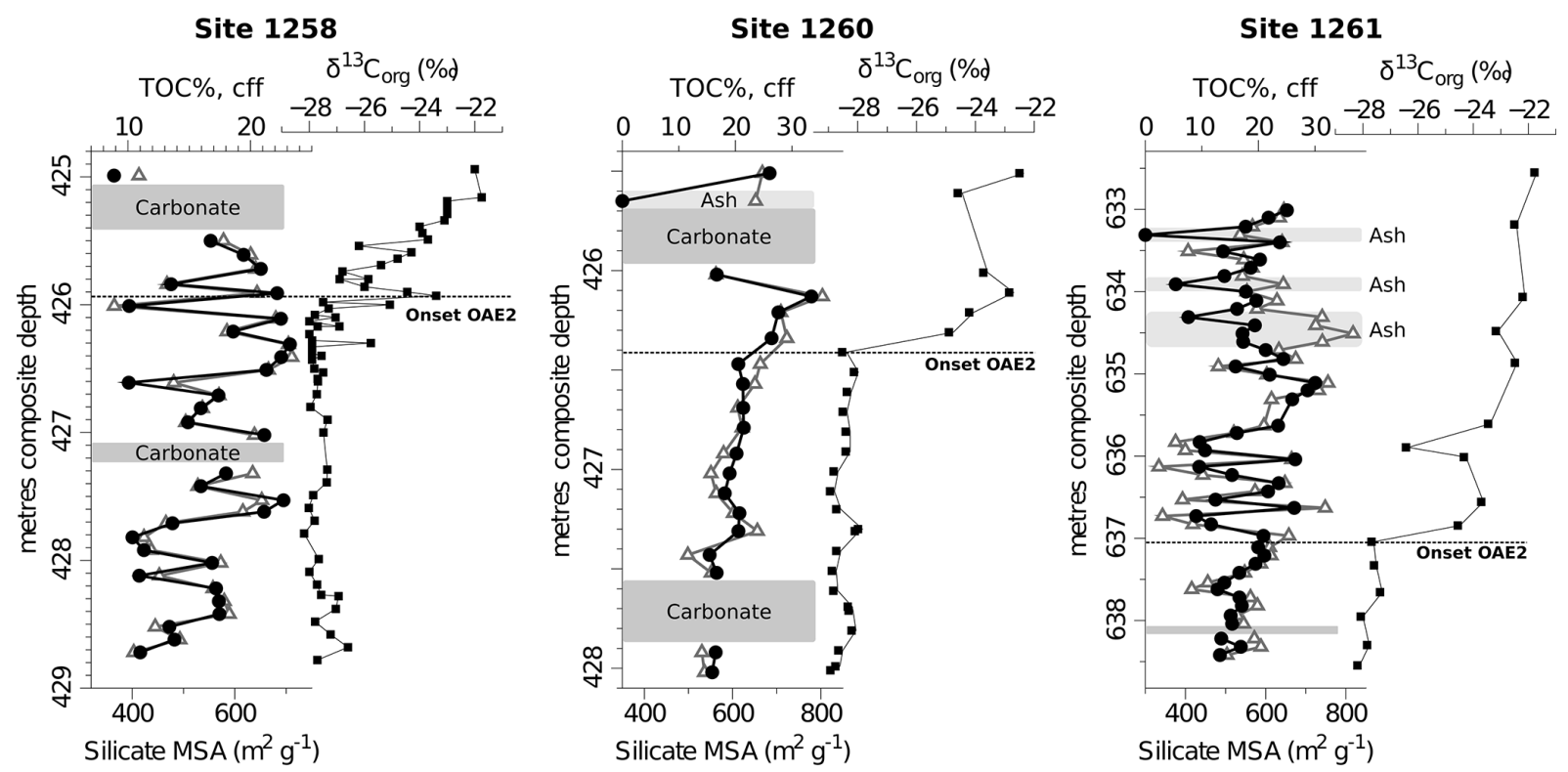

$\triangle$ Silicate MSA $\left(m^{2} g^{-1}\right)-$ TOC\%, carbonate-free fraction $-\delta^{13} \mathrm{Corg}_{\text {or }} \%$

Figure 1. TOC of the carbonate-free fraction closely tracks silicate mineral surface area (MSA) in samples from ODP sites 1258,1260 and 1261, except in ash layers identified at sites 1261 and 1260, where clay mineral formation postdates interaction with organic compounds in the marine and shallow burial environment (Fig. E1). $\delta^{13} \mathrm{C}_{\text {org }}$ data and the interpreted OAE 2 boundary are from Erbacher et al. (2005). Samples from carbonate beds (> $85 \%$ carbonate) are excluded due to the small detrital component and correspondingly large errors introduced by carbonate correction.

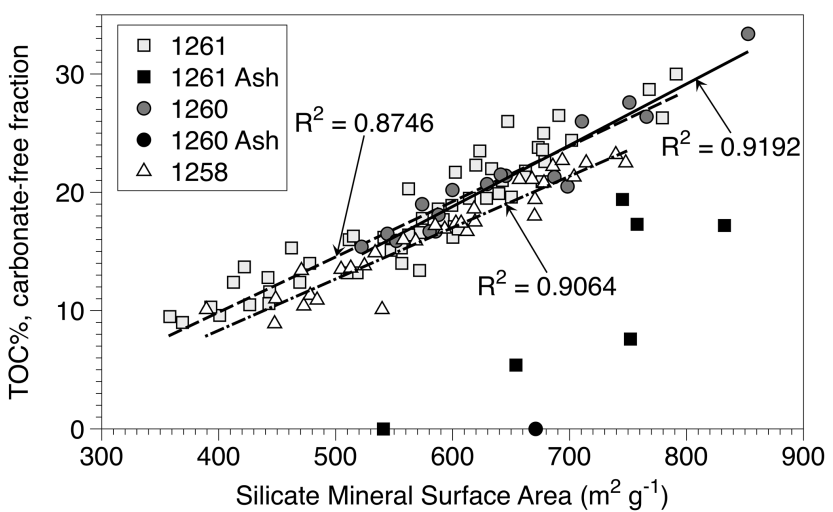

Figure 2. Silicate MSA vs. TOC of the carbonate-free fraction, all sites. Silicate MSA accounts for up to $91.9 \%$ of all TOC variation, excluding ash samples (black) and samples with more than $85 \%$ carbonate (not shown). The organic matter in these samples does not contribute to the surface area determined using the EGME method (Fig. 3), and, in any case, if both minerals and OM independently contributed to surface area, this would not result in a simple linear regression as shown here.

TOC-MSA scaling relationship. However, samples with high TOC relative to MSA are not apparent in our data set, and our high-resolution images show an intimate, sub- $\mu \mathrm{m}$-scale association between clays and OM. Thus, we argue that OC is preserved mainly as sub- $\mu \mathrm{m}$ organic matter in close asso-

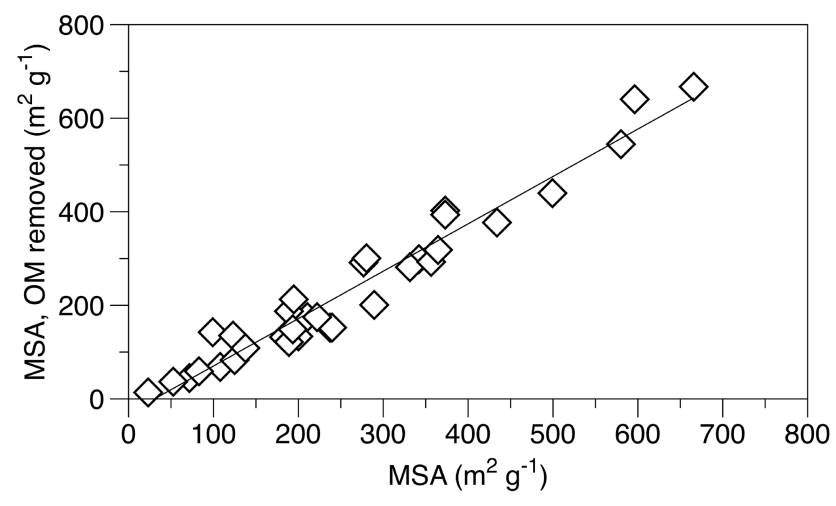

Figure 3. Mineral surface area measured before and after removal of organic matter by $\mathrm{H}_{2} \mathrm{O}_{2}$ remains essentially unchanged $\left(R^{2}=\right.$ 0.95), demonstrating that EGME does not interact with organic matter in the samples. The efficiency of OM removal by $\mathrm{H}_{2} \mathrm{O}_{2}$ ranged from 61 to $95 \%$ (see also the supplementary material).

ciation with clays, rather than as discrete, $\mu \mathrm{m}$-scale organic particles. These findings strongly support a mechanistic link between OC and clays, where the great majority of OC is quantitatively associated with and stabilised by clay mineral surfaces.

Within this context, what is the impact of oxygen availability and productivity on OC enrichment at the Demerara Rise? Measured concentrations of sulfur-bound isorenieratane and 


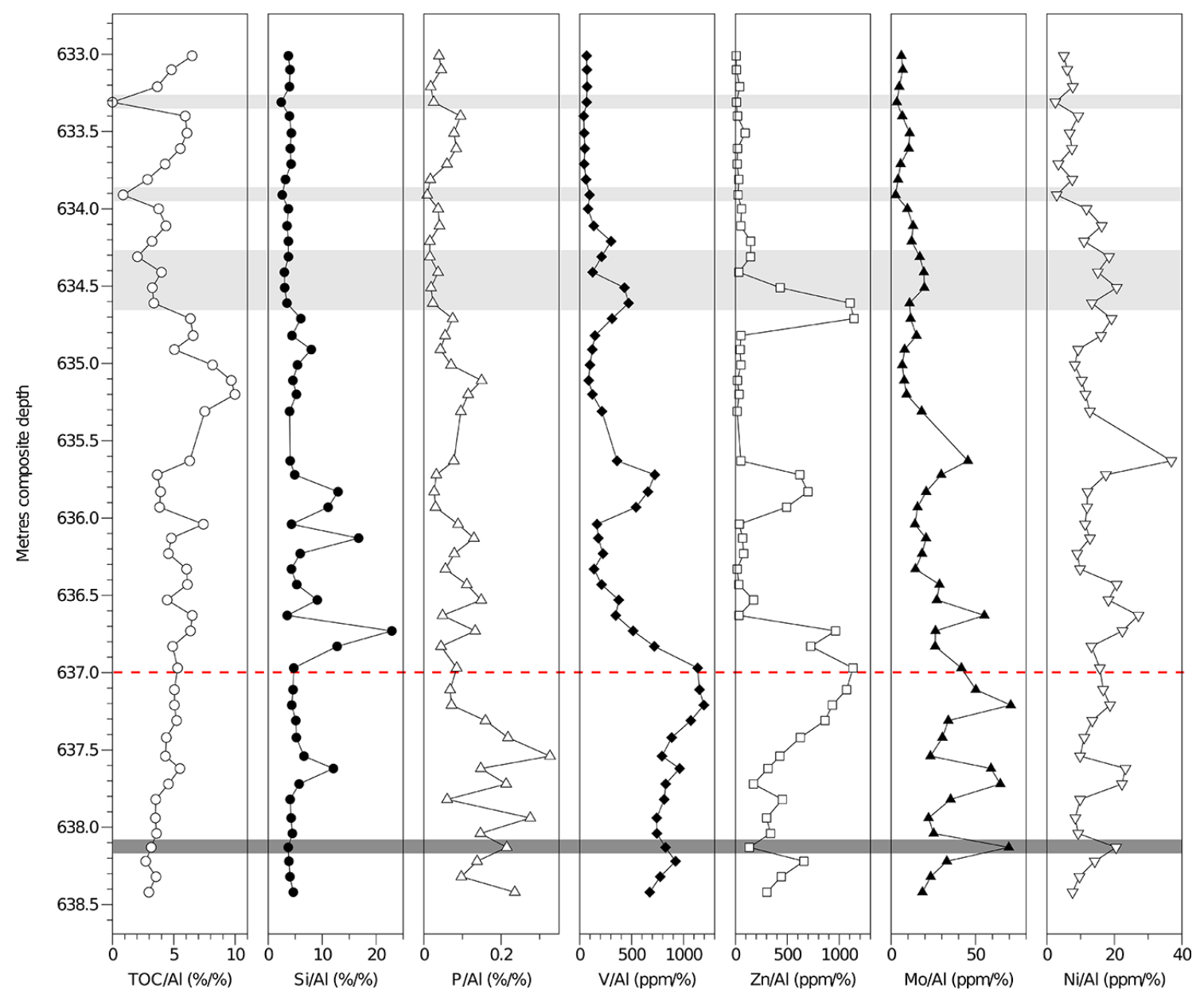

Figure 4. Al-normalised TOC and Si vs. redox-sensitive elements at Site 1261. The interpreted onset of OAE 2 (red) is from Erbacher et al. (2005). Light-grey bars denote altered volcanic ash; the dark-grey zone is a carbonate bed $\left(>85 \% \mathrm{CaCO}_{3}\right)$.

chlorobactane imply that the photic zone was periodically sulfidic (euxinic) both before and during OAE 2 (van Bentum et al., 2009); however, the scattered occurrence of inoceramids (Jiménez Berrocoso et al., 2008) as well as a low abundance and diversity of benthic foraminifera (Friedrich et al., 2006) and fecal pellets and fossils of nektonic fauna (Nederbragt et al., 2007) show that water column euxinia was intermittent. Undisrupted lamination and elevated concentrations of redox-sensitive trace metals (Hetzel et al., 2009) suggest that sea floor anoxic conditions at the Demerara Rise both preceded and postdated the interval identified as OAE 2 . Consistent with these findings, our trace element data suggest continuously oxygen-depleted bottom waters at Site 1261 (Fig. 4). Fluctuating $\mathrm{P} / \mathrm{Al}$ ratios and the intermittent presence of apatite in the pre-OAE 2 section imply redox conditions alternating between (a) anoxic, non-sulfidic conditions permitting apatite precipitation and preservation and (b) sulfidic conditions which resulted in removal of $\mathrm{P}$ released during microbial degradation of OC (Hetzel et al., 2009; März et al., 2008; Tribovillard et al., 2006), whereas persistently lower P concentrations during the OAE 2 interval (Fig. 4) suggest more consistently sulfidic conditions and efficient $\mathrm{P}$ recycling (März et al., 2008). This is supported by short intervals of elevated Al-normalised Mo and Ni concentrations prior to OAE 2, which correspond to low $\mathrm{P}$ intervals, and are indicative of periodically sulfidic conditions, whereas a positive correlation between $\mathrm{Zn}$ and $\mathrm{V}$, as well as Mo and $\mathrm{Ni}$, within the OAE 2 interval is indicative of more persistently sulfidic conditions (Hetzel et al., 2009; Jiménez Berrocoso et al., 2008; Tribovillard et al., 2006). While the continuously oxygen-deficient conditions interpreted on the basis of these results are generally conducive to enhanced OC preservation, all proxy records for oxygen variability fail to reproduce the higher-order sample-to-sample TOC variability (Fig. 4). This is unsurprising, because minor variations in already oxygen-depleted conditions are by themselves unlikely to be expressed as differences in TOC as great as the observed variation from 9 to $26 \%$ in adjacent samples (Tyson, 2005). Fluctuating productivity, on the other hand, is a potential explanation for variable OC enrichment such 

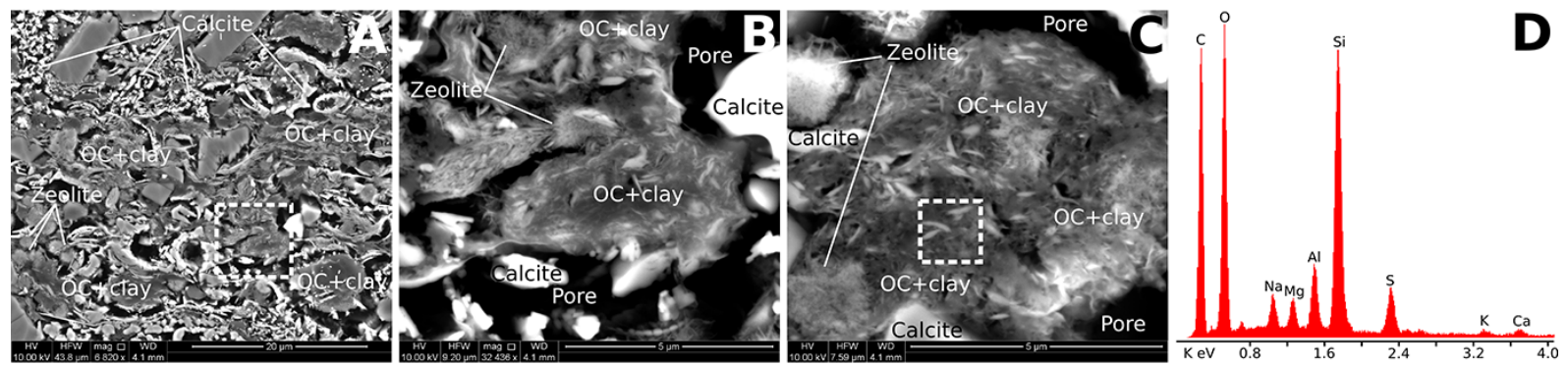

Figure 5. SEM backscatter electron images of Demerara Rise sediments. Organic matter (dark grey in images) is broadly disseminated through the sediment (a), and occurs primarily as sub- $\mu \mathrm{m}$-scale OC coating and aggregated with clays (b, c). Although individual 5-10 $\mu \mathrm{m}$ size aggregates can have the appearance of discrete OM particles (a), closer inspection at higher magnifications (b, c) and energy dispersive $\mathrm{X}$-ray analysis (d, collected from the area marked by the dashed outline in c) reveals the composite clay-organic nature of these zones.
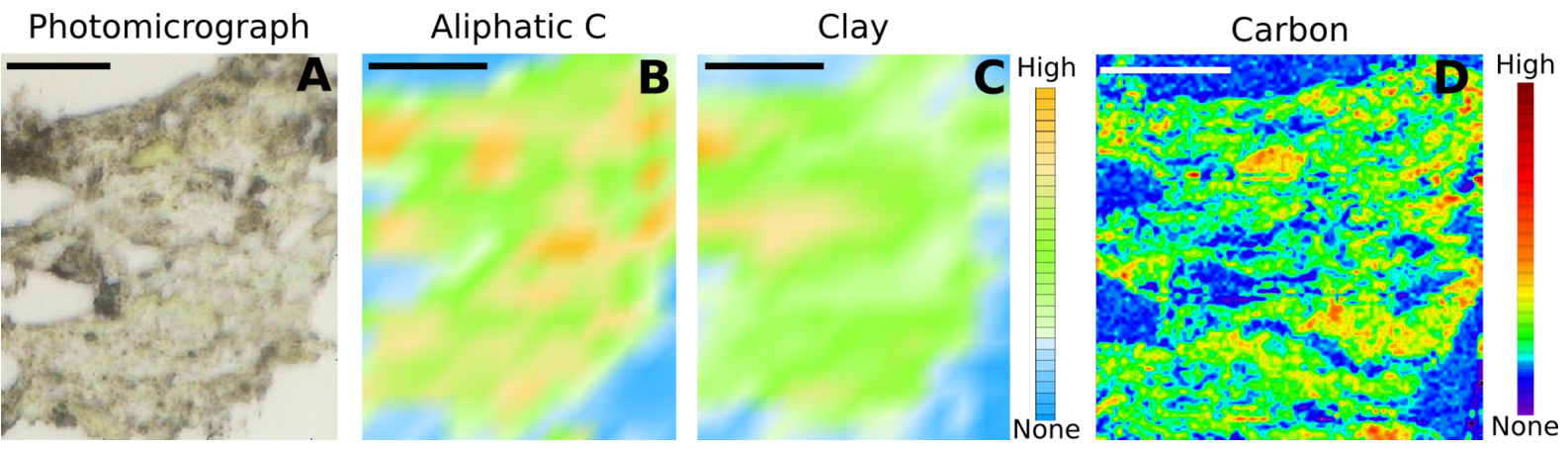

Figure 6. (a) Photomicrograph of a $300 \mathrm{~nm}$ thick, cryomicrotomed ultra-thin section (sample 1258/A/43R/3/71-72). (b) FTIR microspectroscopy maps of aliphatic $\mathrm{C}$ and (c) clay show a broad, overlapping distribution of both over the entire sample ( $5 \mu \mathrm{m}$ resolution), consistent with SEM images (Fig. 5). (d) More detailed, higher-resolution STXM map of C distribution ( $25 \mathrm{~nm}$ spot resolution, $600 \mathrm{~nm}$ step size) in the same sample. Sub- $\mu \mathrm{m}$-scale OC, which is dispersed throughout the sediment (d) in association with the clay mineral matrix (c), and is commonly present in organo-clay aggregates (Fig. 5), represents the bulk of the OC. Scale bar is $20 \mu \mathrm{m}$ in all images.

as observed here (Kuypers et al., 2004). The strongly reducing depositional environment at the Demerara Rise precludes quantitative reconstruction of palaeoproductivity trends using proxies such as $\mathrm{Ba}$ (Hetzel et al., 2009). However, the strong association and constant ratio between TOC and MSA in our data set, and the absence of high or low TOC relative to MSA in particular, demonstrates that the pattern of OC enrichment is not a function of variable OC inputs. While productivity sufficient to saturate available surfaces and maintain anoxic conditions through respiration is an essential requirement, the bulk relationship also necessitates the breakdown of $\mu \mathrm{m}$-scale pelagic organic detritus, which likely represents a source of OC for mineral association within the sediment, and loss of OC in excess of the preservative capacity of the sediment. This is consistent with the downcore loss of OC during early diagenesis observed in modern marine settings (Mayer, 1994) and the low abundance of discrete, $\mu \mathrm{m}$-size organic detritus of pelagic origin in Demerara sediments. Finally, mineral surface association slows but does not stop OC degradation in oxic settings, whereas persistent oxygen depletion increases the preservative capacity of the sediments through lower oxidant concentrations, limited redox oscillations, exclusion of benthic infauna and higher porewater OC, enabling higher OC loadings per unit MSA (Blair and Aller, 2012; Burdige, 2007; Hedges and Keil, 1995; Hedges et al., 1999; Keil and Cowie, 1999). We thus propose that a clay mineral preservative effect combined with persistently oxygen-depleted conditions best explains the variable but high TOC at the Demerara Rise.

The preservative effect on OC afforded by mineral surfaces has been attributed to physicochemical stabilisation by direct sorption of OC to mineral surfaces (Bennett et al., 2012; Curry et al., 2007) and exclusion of microbial decomposers and their exoenzymes by physical encapsulation of labile organic matter (Keil et al., 1994a; Mayer, 1994), but the exact preservative mechanisms remain poorly understood. Given the physical association of OC directly on clay surfaces and the compartmentalised architecture of organoclay aggregates (Fig. 5), it is likely that both encapsulation and sorptive stabilisation contribute to the preservation of OC in organomineral aggregates (Bennett et al., 2012; Curry et al., 2007; Keil and Mayer, 2014). The MSAs measured in this study lie within the range of surface area values characteristic of smectite clay $\left(\sim 750 \mathrm{~m}^{2} \mathrm{~g}^{-1}\right.$; Środon, 


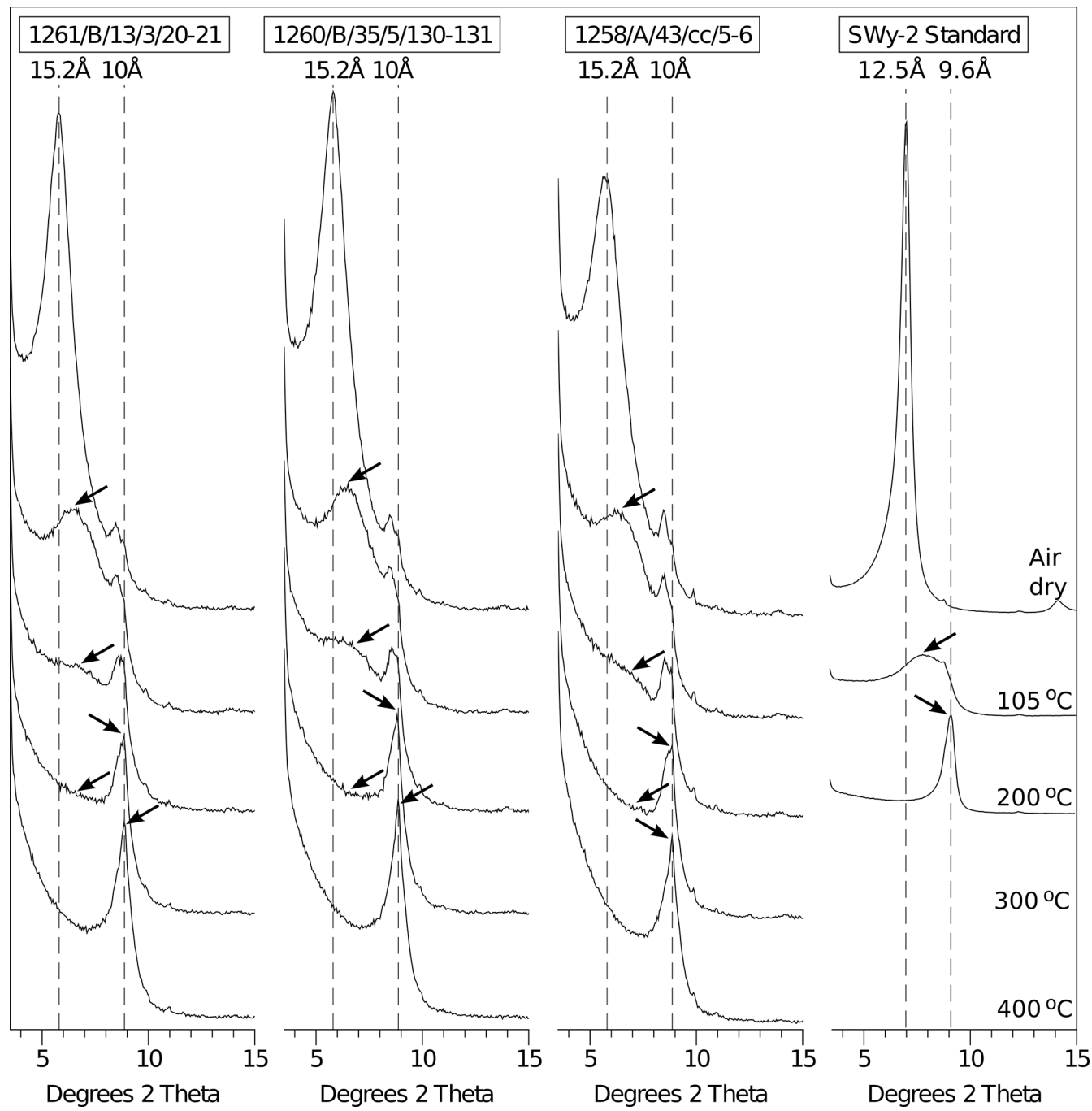

Figure 7. X-ray diffractograms of $<2 \mu \mathrm{m}$ fractions of smectite clay standard (SWy-2, Na-saturated) and three representative Demerara Rise samples after air-drying and heating to the indicated temperatures (oriented preparations). Interlayer dehydration in pure smectite (SWy-2) is achieved by heating to above $105^{\circ} \mathrm{C}$, and results in a complete collapse of the 001 peak to $\approx 10 \AA$ at $200^{\circ} \mathrm{C}$. Demerara Rise samples heated to 105,200 and $300^{\circ} \mathrm{C}$ show an incomplete collapse of the 001 peak (arrows mark main peaks and gradual changes), demonstrating the presence of the intercalated organic matter that is propping open the smectite interlayer after thermal dehydration has occurred (Theng et al., 1986). Although heating progressively broadens and weakens the 001 peak as it shifts from $15.2 \AA$ towards $13-12 \AA$, representing thermal dehydration, complete collapse resulting in a symmetrical peak at $10 \AA$ only occurs after prolonged heating to $400^{\circ} \mathrm{C}$ results in thermal oxidation of the intercalated organic matter.

2009), and smectite interlayer surfaces in particular, implying that these interlayer sites also play an important role in the preservation of nanometer-scale OC. Smectite clays have substantially greater surface areas than other common sedimentary minerals, because smectite layers consist of an octahedral sheet sandwiched between two tetrahedral sheets, and these fundamental units stack together to form an interlayer between them. The interlayer is expandable, so that interlayer sites are accessible to polar and non-polar organic molecules, ions and water (Alimova et al., 2009; Theng et al., 1986; Williams et al., 2005), with the interlayer surface area contributing the bulk of the smectite total sur- face area. The preservative effect on OC by smectite has thus been hypothesised to be the result of incorporation of molecular-scale organic compounds into the smectite interlayer space (Kennedy et al., 2002; Theng et al., 1986), forming refractory organomineral nanocomposites that protect OC molecules from degradation. This is supported by our results. X-ray diffraction of clay separates identifies the dominance of smectite clays in Demerara sediments (Fig. E2), confirming that MSA variation is due to varying smectite content, and clearly identifies the organomineral nanocomposite nature of this material (Fig. 7), where a component of $\mathrm{OM}$ is preserved as molecular-scale OM intercalated 
within the smectite interlayer. Independent palynologic analysis (Summerhayes, 1981) of Demerara Rise sediments is consistent with our evidence for organomineral intercalation and mineral-associated OC preservation. These analyses rely on the dissolution of the silicate fraction to concentrate OM, and show that more than $90 \%$ of Demerara Rise OM is amorphous and of unrecognisable origin, likely comprising the acid-insoluble residue of previously mineral-associated organic material. Consistent with our interpretation, recognisable organic detritus does not constitute a quantitatively significant component of sediment TOC (Summerhayes, 1981).

The $\mathrm{x}$-axis intercepts of the Demerara Rise MSA / TOC regressions (Fig. 2) are offset from zero $\left(\approx 200 \mathrm{~m}^{2} \mathrm{~g}^{-1}\right)$. This is similar to offsets of $\approx 260 \mathrm{~m}^{2} \mathrm{~g}^{-1}$ and $\approx 290 \mathrm{~m}^{2} \mathrm{~g}^{-1}$ for the anoxic/suboxic and oxic facies, respectively, of OAE 3 at ODP Site 959 (Deep Ivorian Basin; Kennedy and Wagner, 2011), and an offset of $\approx 60 \mathrm{~m}^{2} \mathrm{~g}^{-1}$ for the Cretaceous Pierre Shale (Kennedy et al., 2002). This x-intercept offset implies MSA that did not acquire OM or subsequently lost $\mathrm{OM}$. It has previously been interpreted as reflecting the loss of a more readily oxidised fraction of OM that was associated with external clay mineral surfaces and edges (which can exceed $200 \mathrm{~m}^{2} \mathrm{~g}^{-1}$ in smectitic sediments), whereas OM preserved within the smectite interlayer is considered to be more refractory (Kennedy and Wagner, 2011; Kennedy et al., 2014). However, SEM observations of organoclay aggregates from the Demerara Rise identify a component of OM associated with external clay surfaces, encapsulated within organoclay aggregates. The observed offsets may be the product of lower OM concentrations in the outermost zone of these aggregates. OM encapsulated by and sorbed to clays in aggregate interiors is progressively better protected relative to OM initially present closer to the aggregate exterior (Keil and Mayer, 2014), as also documented for soil organomineral aggregates (Kinyangi et al., 2006).

Finally, the slope of the MSA-to-TOC regression has been shown to vary as a function of the depositional environment, sediment diagenesis, and oxic vs. anoxic sediments (Blair and Aller, 2012; Kennedy and Wagner, 2011). While TOC generally correlates with MSA in modern continental margin sediments, the highest OM loadings per unit MSA (slope) are found in sediments from high productivity and/or oxygendepleted settings, whereas the lowest loadings are typical of sediments from higher energy settings or deep-sea deposits that are subject to long oxidant exposure times (Blair and Aller, 2012). Similar differences are apparent in ancient sediments, with higher OM loadings recorded in samples from anoxic facies $\left(0.7 \mathrm{mg} \mathrm{OC} \mathrm{m}^{-2}\right)$ compared to oxic and suboxic facies $\left(0.4 \mathrm{mg} \mathrm{OC} \mathrm{m}^{-2}\right)$ at ODP Site 959 (Kennedy and Wagner, 2011). While the ODP 959 and Demerara Rise data sets largely overlap, the slope of the MSA-to-TOC regression at Demerara Rise sites ranges from $0.44 \mathrm{mg} \mathrm{OC} \mathrm{m}^{-2}$ (Site 1258) to $0.52 \mathrm{mg} \mathrm{OC} \mathrm{m}^{-2}$ (Site 1260), somewhat lower than the laminated, anoxic facies at Site 959, but greater than the oxic to suboxic facies at Site 959. Although this might in- dicate greater oxidant exposure at the Demerara Rise relative to Site 959, comparisons to modern sediments show that OM loading ratios are equally reduced in relatively higher energy, lower productivity, or lower sedimentation rate settings.

\section{Conclusions}

The organic carbon deposits defining OAE 2 are widely considered a response to increased productivity and reduced oxidant concentration in seawater, likely triggered by volcanism. Our results show that high but variable OC enrichment at the Demerara Rise, including the OAE 2 interval, is due to the intersection of consistently oxygen-depleted conditions and variable deposition of detrital smectite clay capable of forming refractory organomineral nanocomposites and aggregates, representing a continental influence. However, can the smectite influence on OC burial identified at the Demerara Rise potentially explain anomalous OC enrichment during OAE 2 at other geographically distant locations, given that smectite formation in soils is spatially constrained by zonal climate (Chamley, 1989)?

Smectite is also a major weathering product of continental volcanic deposits. Volcanism can lead to regional- or even basinal-scale increases in smectite concentration because of transport of this finest clay fraction over 100s or even 1000s of $\mathrm{km}$ along basin margins (Chamley, 1989). Sr, Os, $\mathrm{Nd}$ and $\mathrm{S}$ isotope anomalies measured across the $\mathrm{C}$ isotope excursion that defines OAE 2 show an increase in mantle-derived fluids at geographically distant locations (Adams et al., 2010; Jones and Jenkyns, 2001; Martin et al., 2012; Turgeon and Creaser, 2008). This is closely timed with the emplacement of the Caribbean and Madagascar large igneous provinces (Kerr, 1998; Sinton and Duncan, 1997) and the production and geographic dispersal of easily weathered volcanic materials from these sources (Kuroda et al., 2007). Thus, a pulse of sub-aqueous (Turgeon and Creaser, 2008) and sub-aerial (Kuroda et al., 2007) volcanism coinciding with OAE 2 may not only have stimulated marine productivity (Adams et al., 2010) and contributed to the geographic expansion of anoxic conditions (Sinton and Duncan, 1997), but increased subaerial weathering of volcanic material may also have amplified the flux of detrital smectite to continental margin settings (Nadeau and Reynolds, 1981), producing conditions conducive to the anomalous accumulation of OC during OAE 2. If confirmed, this would represent a previously unrecognised negative feedback mechanism that balances $\mathrm{CO}_{2}$ produced during widespread phases of volcanism with the removal of $\mathrm{CO}_{2}$ through enhanced sequestration of organic matter as organomineral nanocomposites. 


\section{Appendix A: SEM analyses}

Organic matter morphology, distribution and mineral association were determined at $\mathrm{mm}$ to sub- $\mu \mathrm{m}$ scales using a FEI Quanta 450 environmental scanning electron microscope system equipped with a backscattered electron (BSE) detector and an energy dispersive X-ray (EDAX) analyser. Prior to imaging, samples were fixed onto SEM stubs with the imaged surface prepared perpendicular to bedding. Samples were gently dry ground until flat, cleaned with compressed nitrogen, ion milled until polished (Fischione 1010 Ar Ion Mill system), and coated with $5 \mathrm{~nm} \mathrm{Pt}$.

\section{Appendix B: Synchrotron imaging sample preparation}

Transmission imaging requires the preparation of intact ultrathin sections. A cryomicrotoming approach was utilised in order to avoid embedding samples in carbon-based resin (Lehmann et al., 2008). Intact shale subsamples were mounted onto microtome pins and saturated in ultrapure water overnight. Excess water was drained on a filter paper, after which samples were plunge frozen in liquid nitrogen. Thin sections (300 nm thickness) were cryomicrotomed (Leica Ultracut $\mathrm{S}$ ) across the shale bedding plane at $-80^{\circ} \mathrm{C}$ using a diamond knife at a cutting speed of $2.5 \mathrm{~mm} \mathrm{~s}^{-1}$. Sections were then transferred and pressed onto $\mathrm{C}$-free $\mathrm{Cu}$ grids (200 mesh with $\mathrm{SiO}$ membrane, no. 53002, Ladd Research, Williston, VT) before being air dried.

\section{Appendix C: IR data collection and analysis}

Fourier transform infrared (FTIR) spectra of the cryomicrotomed ultra-thin sections were collected in transmission mode at the infrared microspectroscopy beamline at the Australian Synchrotron. The beamline is equipped with a Bruker Hyperion 2000 microscope with a Vertex V80v FTIR spectrometer, and a narrow-band, high-sensitivity liquid nitrogencooled mercury cadmium telluride detector. Spectral maps of the thin sections were recorded with a $5 \mu \mathrm{m}$ aperture size and a step size of $5 \mu \mathrm{m}$, a spectral range of $3900-700 \mathrm{~cm}^{-1}$ and a spectral interval of $4 \mathrm{~cm}^{-1}$. Each spectrum was composed of 64 scans added before Fourier transformation. All spectra were corrected for adsorption from the grid membrane by normalising to the spectrum of an empty region of the grid. FTIR data were processed using Bruker OPUS 6.5 software (Bruker Optics, Billerica, Massachusetts, USA). Spectral maps were created after cropping to a spectral region of $3800-850 \mathrm{~cm}^{-1}$ and automatic baseline correction (concave rubber-band method, 10 iterations, 64 baseline points). Maps were created for maximum peak heights in the following ranges: $2935-2920 \mathrm{~cm}^{-1}$ and $1060-1020 \mathrm{~cm}^{-1}$. A peak position at $2935-2920 \mathrm{~cm}^{-1}$ corresponds to $\mathrm{C}-\mathrm{H}$ stretching vibrations of aliphatic C (Haberhauer et al., 1998; Lehmann et al., 2007) and at $1060-1020 \mathrm{~cm}^{-1}$ to the principal $\mathrm{SiO}$ stretching band of smectite, illite or interstratified illitesmectite (Russell and Fraser, 1994).

\section{Appendix D: STXM data collection and analysis}

Scanning transmission X-ray microscope (STXM) maps of nanoscale $\mathrm{C}$ distribution were collected at the PolLux beamline of the Swiss Light Source, which is situated on a bend magnet-type synchrotron beamline that provides a linearly polarised X-ray beam with a photon energy range between approximately $250 \mathrm{eV}$ and $1600 \mathrm{eV}$. Detailed descriptions of the beamline and applications of the STXM technique have been published elsewhere (Raabe et al., 2008). Briefly, while a monochromatic X-ray beam is focused on the sample by a Fresnel zone plate $(25 \mathrm{~nm}$ outer zone width), the sample is scanned through the beam, and the transmitted intensity yields the 2-D image with a focus spot size of about $25 \mathrm{~nm}$ (Raabe et al., 2008; Watts and Ade, 2012). Element-specific contrast stems from differing $\mathrm{X}$-ray absorption at energies below and above the element-specific absorption edge, which is approximately $300 \mathrm{eV}$ at the $\mathrm{C} \mathrm{K}$-edge (Watts and Ade, 2012). The ratio of images taken below and above the absorption edge then shows the distribution and concentration of the element of interest. Accordingly, each ultra-thin section was scanned at 280 and $320 \mathrm{eV}$ using a spot resolution of $25 \mathrm{~nm}$, a step size of $600 \mathrm{~nm}$ and a dwell time of $5 \mathrm{~ms}$. Selected areas where then scanned at higher resolution, typically with a step size of $50 \mathrm{~nm}$, all other parameters remaining unchanged. 


\section{Appendix E: Additional figures}
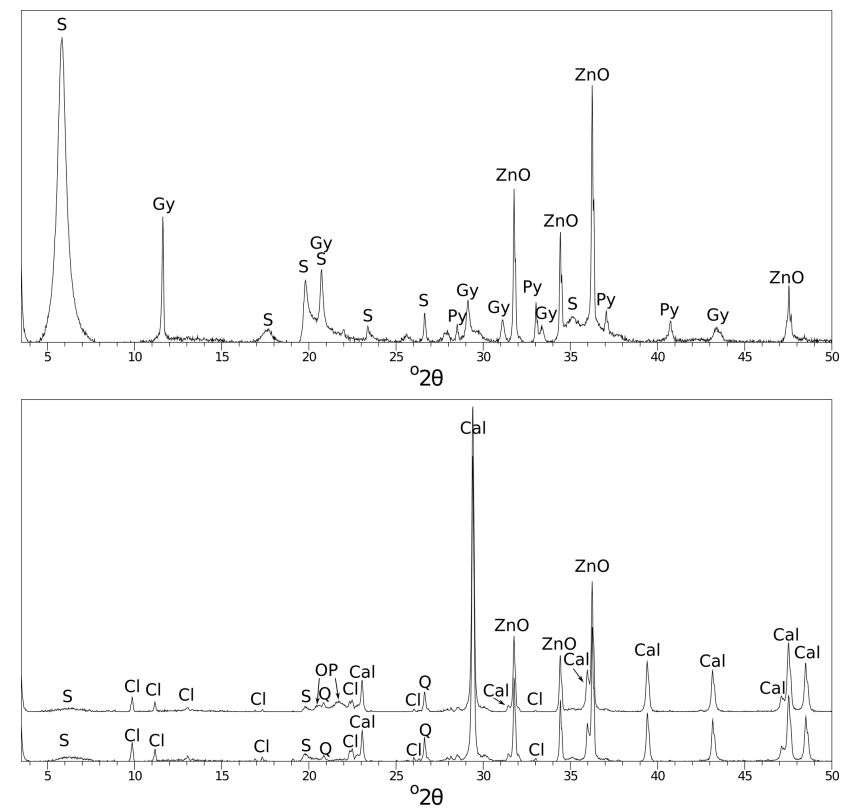

Figure E1. X-ray diffractograms of an altered ash layer sample (upper panel; sample 1261/A/48R/5/30-31) and two typical nonash layer samples (lower panel; samples 1258/A/43R/2/65-66 and 1258/A/43R/2/85-86). The samples showing elevated MSA with relatively low TOC at sites 1260 and 1261 are altered volcanic ash (bentonite). These samples are composed mainly of smectite clay, and lack other detrital or biogenic phases typical of other Demerara Rise sediments. Diagenetic smectite forms after burial by in situ alteration of volcanic glass in ash beds, and does not exhibit the MSA-OC associations of detrital smectite, because the diagenetic smectite forms after the sediment is decoupled from OC sources in the water column or pore water. S: smectite; Gy: gypsum; Py: pyrite; $\mathrm{Cl}$ : clinoptilolite; OP: opal CT; Q: quartz; Cal: calcite; $\mathrm{ZnO}$ : zinc oxide internal standard.

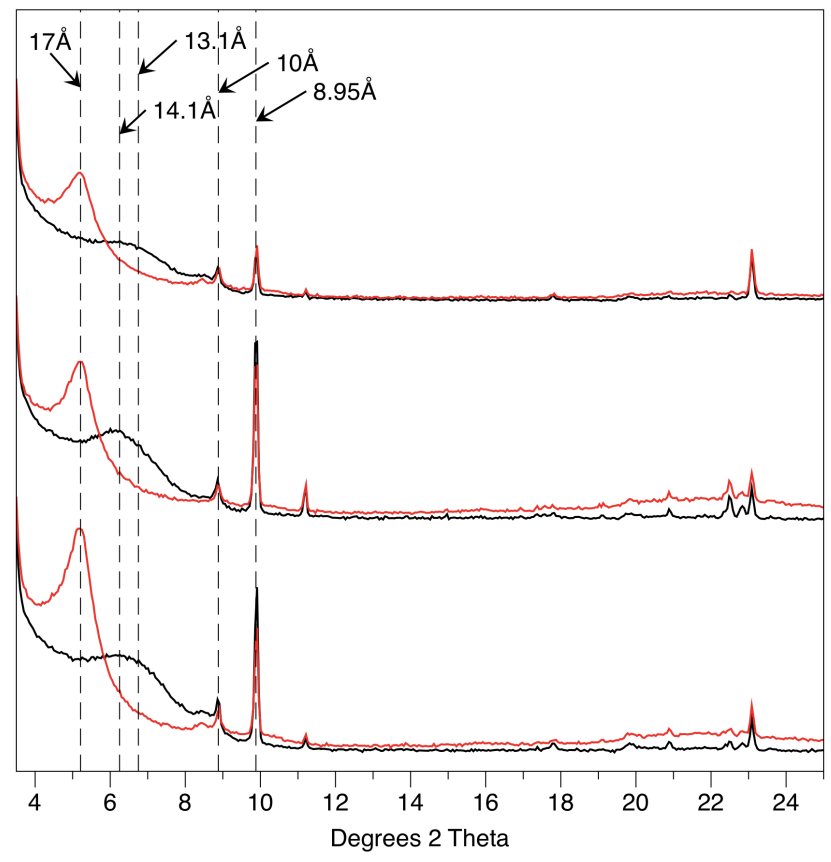

Figure E2. Air-dried (black) and ethylene glycol-treated (red) Xray diffractograms of the $<5 \mu \mathrm{m}$ fraction show a predominance of smectite (expands from $13-14$ to $17 \AA$ after glycolation) and smaller amounts of discrete illite $(10 \AA)$ in Demerara Rise samples. Clinoptilolite, a diagenetic zeolite, is also present in this size fraction in many samples (8.95 $)$ ). Top: 1261/A/49R/1/95-96; middle: 1261/A/48R/5/130-131; bottom: 1261/A/48R/4/65-66. 


\section{The Supplement related to this article is available online at doi:10.5194/bg-11-4971-2014-supplement.}

Acknowledgements. We thank the Australian Research Council for financial support (ARC Discovery Project DP110103367 to M. J. Kennedy), and we acknowledge travel funding (AS/IA122/5177) provided by the International Synchrotron Access Program (ISAP) managed by the Australian Synchrotron and funded by the Australian Government. We thank J. Brugger and B. Etschmann for their help with the FTIR and STXM experiments, and staff at Adelaide Microscopy for assistance with sample preparation. FTIR experiments were undertaken at the Australian Synchrotron. STXM experiments were performed on the X07DA (PolLux) beamline of the Swiss Light Source. This research used samples and data provided by the Ocean Drilling Program (ODP). ODP is sponsored by the US National Science Foundation (NSF) and participating countries under the management of Joint Oceanographic Institutions (JOI), Inc.

Edited by: H. Kitazato

\section{References}

Adams, D. D., Hurtgen, M. T., and Sageman, B. B.: Volcanic triggering of a biogeochemical cascade during Oceanic Anoxic Event 2, Nat. Geosci., 3, 201-204, doi:10.1038/NGEO743, 2010.

Alimova, A., Katz, A., Steiner, N., Rudolph, E., Wei, H., Steiner, J. C., and Gottlieb, P.: Bacteria-Clay Interaction: Structural Changes in Smectite Induced During Biofilm Formation, Clays Clay Miner., 57, 205-212, doi:10.1346/CCMN.2009.0570207, 2009.

Arthur, M. A. and Sageman, B. B.: Marine Black Shales - Depositional Mechanisms and Environments of Ancient Deposits, Annu. Rev. Earth Pl. Sc., 22, 499-551, 1994.

Arthur, M. A., Schlanger, S. O., and Jenkyns, H. C.: The Cenomanian-Turonian Oceanic Anoxic Event, II. Palaeoceanographic controls on organic-matter production and preservation, Geol. Soc. SP, 26, 401-420, 1987.

Arthur, M. A., Dean, W. E., and Pratt, L. M.: Geochemical and Climatic Effects of Increased Marine Organic-Carbon Burial at the Cenomanian Turonian Boundary, Nature, 335, 714-717, 1988.

Beckmann, B., Flögel, S., Hofmann, P., Schulz, M., and Wagner, T.: Orbital forcing of Cretaceous river discharge in tropical Africa and ocean response, Nature, 437, 241-244, doi:10.1038/nature03976, 2005.

Bennett, R. H., Hulbert, M. H., Curry, K. J., Curry, A., and Douglas, J.: Organic matter sequestered in potential energy fields predicted by 3-D clay microstructure model: Direct observations of organo-clay micro- and nanofabric, Mar. Geol., 315-318, 108114, 2012.

Bice, K. and Norris, R.: Possible atmospheric $\mathrm{CO}_{2}$ extremes of the Middle Cretaceous (late Albian-Turonian), Paleoceanography, 17, 1070, doi:10.1029/2002PA000778, 2002.

Blair, N. E. and Aller, R. C.: The Fate of Terrestrial Organic Carbon in the Marine Environment, Annu. Rev. Mar. Sci., 4, 401-423, doi:10.1146/annurev-marine-120709-142717, 2012.
Burdige, D. J.: Preservation of Organic Matter in Marine Sediments: Controls, Mechanisms, and an Imbalance in Sediment Organic Carbon Budgets? Chem. Rev., 107, 467-485, doi:10.1021/cr050347q, 2007.

Chamley, H.: Clay Sedimentology, Springer Verlag, Berlin, 1989.

Curry, K. J., Bennett, R. H., Mayer, L. M., Curry, A., Abril, M., Biesiot, P. M., and Hulbert, M. H.: Direct visualization of clay microfabric signatures driving organic matter preservation in fine-grained sediment, Geochim. Cosmochim. Ac., 71, 17091720, doi:10.1016/j.gca.2007.01.009, 2007.

Erbacher, J., Friedrich, O., Wilson, P., Birch, H., and Mutterlose, J.: Stable organic carbon isotope stratigraphy across Oceanic Anoxic Event 2 of Demerara Rise, western tropical Atlantic, Geochem. Geophy. Geosy., 6, Q06010, doi:10.1029/2004GC000850, 2005.

Forster, A., Sturt, H., Meyers, P. A., and the Leg 207 Shipboard Scientific Party: Molecular biogeochemistry of Cretaceous Black Shales from the Demerara Rise: Preliminary Shipboard Results from Sites 1257 and 1258, Leg 207, in: Proceedings of the Ocean Drilling Program, Initial Reports, vol. 207, edited by: Erbacher, J., Mosher, D. C., and Malone, M. J., 2004.

Friedrich, O., Erbacher, J. ,and Mutterlose, J.: Paleoenvironmental changes across the Cenomanian/Turonian Boundary Event (Oceanic Anoxic Event 2) as indicated by benthic foraminifera from the Demerara Rise (ODP Leg 207), Revue de Micropaléontologie, 49, 121-139, 2006.

Friedrich, O., Norris, R. D., and Erbacher, J.: Evolution of middle to Late Cretaceous oceans-A 55 m.y. record of Earth's temperature and carbon cycle, Geology, 40, 107-110, doi:10.1130/G32701.1, 2012.

Haberhauer, G., Rafferty, B., Strebl, F., and Gerzabek, M.: Comparison of the composition of forest soil litter derived from three different sites at various decompositional stages using FTIR spectroscopy, Geoderma, 83, 331-342, 1998.

Hedges, J. and Keil, R. G.: Sedimentary Organic-Matter Preservation - an Assessment and Speculative Synthesis, Mar. Chem., 49, 81-115, 1995.

Hedges, J., Hu, F., Devol, A., Hartnett, H., Tsamakis, E., and Keil, R. G.: Sedimentary organic matter preservation: A test for selective degradation under oxic conditions, Am. J. Sci., 299, 529$555,1999$.

Hetzel, A., Boettcher, M. E., Wortmann, U. G., and Brumsack, H.J.: Paleo-redox conditions during OAE 2 reflected in Demerara Rise sediment geochemistry (ODP Leg 207), Palaeogeogr. Palaeocl., 273, 302-328, doi:10.1016/j.palaeo.2008.11.005, 2009.

Jenkyns, H. C.: Geochemistry of oceanic anoxic events, Geochem Geophy Geosy, 11, Q03004, doi:10.1029/2009GC002788, 2010.

Jiménez Berrocoso, A., MacLeod, K. G., Calvert, S. E., and Elorza, J.: Bottom water anoxia, inoceramid colonization, and benthopelagic coupling during black shale deposition on Demerara Rise (Late Cretaceous western tropical North Atlantic), Paleoceanography, 23, PA3212, doi:10.1029/2007PA001545, 2008.

Jones, C. and Jenkyns, H.: Seawater strontium isotopes, oceanic anoxic events, and seafloor hydrothermal activity in the Jurassic and Cretaceous, Am. J. Sci., 301, 112-149, 2001.

Kaiho, K. and Hasegawa, T.: End-Cenomanian Benthic Foraminiferal Extinctions and Oceanic Dysoxic Events in 
the Northwestern Pacific-Ocean, Palaeogeogr. Palaeocl., 111, 29-43, 1994.

Keil, R. G. and Cowie, G. L.: Organic matter preservation through the oxygen-deficient zone of the NE Arabian Sea as discerned by organic carbon:mineral surface area ratios, Mar. Geol., 161, 13-22, doi:10.1016/S0025-3227(99)00052-3, 1999.

Keil, R. G. and Mayer, L. M.: Mineral Matrices and Organic Matter, in Treatise on Geochemistry, 337-359, Elsevier, 2014.

Keil, R. G., Montlucon, D. B., Prahl, F. G., and Hedges, J.: Sorptive Preservation of Labile Organic-Matter in Marine-Sediments, Nature, 370, 549-552, 1994a.

Keil, R. G., Tsamakis, E., Fuh, C. B., Giddings, J. C., and Hedges, J.: Mineralogical and textural controls on the organic composition of coastal marine sediments: Hydrodynamic separation using SPLITT-fractionation, Geochim. Cosmochim. Ac., 58, 879893, 1994b.

Kennedy, M. J. and Wagner, T.: Clay mineral continental amplifier for marine carbon sequestration in a greenhouse ocean, P. Natl. Acad. Sci. USA, 108, 9776-9781, doi:10.1073/pnas.1018670108, 2011.

Kennedy, M. J., Pevear, D., and Hill, R.: Mineral Surface Control of Organic Carbon in Black Shale, Science, 295, 657-660, doi:10.1126/science.1066611, 2002.

Kennedy, M. J., Löhr, S. C., Fraser, S. A., and Baruch, E. T.: Direct evidence for organic carbon preservation as clayorganic nanocomposites in a Devonian black shale; from deposition to diagenesis, Earth Planet. Sc. Lett., 388, 59-70, doi:10.1016/j.epsl.2013.11.044, 2014.

Kerr, A. C.: Oceanic plateau formation: a cause of mass extinction and black shale deposition around the Cenomanian-Turonian boundary?, J. Geol. Soc. Lond., 155, 619-626, 1998.

Kinyangi, J., Solomon, D., Liang, B., Lerotic, M., Wirick, S., and Lehmann, J.: Nanoscale biogeocomplexity of the organomineral assemblage in soil: Application of STXM microscopy and C 1sNEXAFS spectroscopy, Soil Sci. Soc. Am. J., 70, 1708-1718, doi:10.2136/sssaj2005.0351, 2006.

Kuroda, J., Ogawa, N. O., Tanimizu, M., Coffin, M. F., Tokuyama, H., Kitazato, H., and Ohkouchi, N.: Contemporaneous massive subaerial volcanism and late cretaceous Oceanic Anoxic Event 2, Earth Planet. Sc. Lett., 256, 211-223, doi:10.1016/j.eps1.2007.01.027, 2007.

Kuypers, M. M. M., Lourens, L. J., Rijpstra, W., Pancost, R., Nijenhuis, I. A., and Sinninghe Damsté, J. S.: Orbital forcing of organic carbon burial in the proto-North Atlantic during oceanic anoxic event 2, Earth Planet. Sci. Lett., 228, 465-482, doi:10.1016/j.epsl.2004.09.037, 2004.

Lehmann, J., Kinyangi, J., and Solomon, D.: Organic matter stabilization in soil microaggregates: implications from spatial heterogeneity of organic carbon contents and carbon forms, Biogeochemistry, 85, 45-57, doi:10.1007/s10533-007-9105-3, 2007.

Lehmann, J., Solomon, D., Kinyangi, J., Dathe, L., Wirick, S., and Jacobsen, C.: Spatial complexity of soil organic matter forms at nanometre scales, Nat. Geosci., 1, 238-242, doi:10.1038/ngeo155, 2008.

Martin, E. E., MacLeod, K. G., Jiménez Berrocoso, A., and Bourbon, E.: Water mass circulation on Demerara Rise during the Late Cretaceous based on $\mathrm{Nd}$ isotopes, Earth Planet. Sc. Lett., 327-328, 111-120, doi:10.1016/j.epsl.2012.01.037, 2012.
März, C., Poulton, S. W., Beckmann, B., Kuester, K., Wagner, T., and Kasten, S.: Redox sensitivity of $\mathrm{P}$ cycling during marine black shale formation: Dynamics of sulfidic and anoxic, nonsulfidic bottom waters, Geochim. Cosmochim. Ac., 72, 37033717, doi:10.1016/j.gca.2008.04.025, 2008.

Mayer, L. M.: Surface-Area Control of Organic-Carbon Accumulation in Continental-Shelf Sediments, Geochim. Cosmochim. Ac., 58, 1271-1284, 1994.

Meyers, P. A., Bernasconi, S. M., and Forster, A.: Origins and accumulation of organic matter in expanded Albian to Santonian black shale sequences on the Demerara Rise, South American margin, Org. Geochem., 37, 1816-1830, doi:10.1016/j.orggeochem.2006.08.009, 2006.

Mort, H. P., Jacquat, O., Adatte, T., Steinmann, P., Foellmi, K., Matera, V., Berner, Z., and Stueben, D.: The Cenomanian/Turonian anoxic event at the Bonarelli level in Italy and Spain: enhanced productivity and/or better preservation?, Cretaceous Res., 28, 597-612, doi:10.1016/j.cretres.2006.09.003, 2007.

Nadeau, P. H. and Reynolds, R. C.: Volcanic components in pelitic sediments, Nature, 294, 72-74, doi:10.1038/294072a0, 1981.

Nederbragt, A. J., Thurow, J., and Pearce, R.: Sediment composition and cyclicity in the mid-Cretaceous at Demerara Rise, ODP Leg 207, in: Proc. ODP, Sci. Results, 207, vol. 207, edited by: Mosher, D. C., Erbacher, J., Malone, M. J., and Garrison, R. E., 1-31, Ocean Drilling Program, College Station TX, 2007.

Orth, C. J., Attrep, M., Quintana, L., Elder, W., Kauffman, E., Diner, R. and Villamil, T.: Elemental Abundance Anomalies in the Late Cenomanian Extinction Interval - a Search for the Source(S), Earth Planet. Sc. Lett., 117, 189-204, 1993.

Pratt, L. M.: Influence of paleoenvironmental factors on preservation of organic matter in Middle Cretaceous Greenhorn formation, Pueblo Colorado, Amer. Assoc. Petroleum Geol. Bull., 68, 1146-1159, 1984.

Raabe, J., Tzvetkov, G., Flechsig, U., Boege, M., Jaggi, A., Sarafimov, B., Vernooij, M. G. C., Huthwelker, T., Ade, H., Kilcoyne, D., Tyliszczak, T., Fink, R. H., and Quitmann, C.: PolLux: A new facility for soft x-ray spectromicroscopy at the Swiss Light Source, Rev. Sci. Instrum., 79, 113704, doi:10.1063/1.3021472, 2008.

Ransom, B., Kim, D., Kastner, M. and Wainwright, S.: Organic matter preservation on continental slopes: Importance of mineralogy and surface area, Geochim. Cosmochim. Ac., 62, 1329-1345, 1998.

Russell, J. D. and Fraser, A. R.: Infrared Methods, in: Clay Mineralogy: Spectroscopic and Chemical Determinative Methods, edited by: Wilson, M. J., 11-67, Chapman \& Hall, London. 1994.

Schlanger, S. O. and Jenkyns, H. C.: Cretaceous oceanic anoxic events: causes and consequences, Geologie Mijnbouw, 55, 179184, 1976.

Sherrod, L., Dunn, G., Peterson, G., and Kolberg, R.: Inorganic carbon analysis by modified pressure-calcimeter method, Soil Sci. Soc. Am. J., 66, 299-305, 2002.

Sinton, C. and Duncan, R.: Potential links between ocean plateau volcanism and global ocean anoxia at the Cenomanian-Turonian boundary, Econ. Geol. Bull. Soc., 92, 836-842, 1997.

Summerhayes, C. P.: Organic Facies of Middle Cretaceous Black Shales in Deep North Atlantic, AAPG Bulletin, 65, 2364-2380, 1981. 
Środoń, J.: Quantification of illite and smectite and their layer charges in sandstones and shales from shallow burial depth, Clay Miner., 44, 421-434, doi:10.1180/claymin.2009.044.4.421, 2009.

Takashima, R., Nishi, H., Huber, B. T., and Leckie, R. M.: Greenhouse world and the Mesozoic ocean, Oceanography, 19, 82-92, 2006.

Theng, B. K. G., Churchman, G. J., and Newman, R. H.: The Occurence of Interlayer Clay-Organic Complexes in Two New Zealand Soils, Soil Sci., 142, 262-266, 1986.

Tiller, K. G. and Smith, L. H.: Limitations of EGME Retention to Estimate the Surface-Area of Soils, Aust. J. Soil Res., 28, 1-26, 1990.

Tribovillard, N., Algeo, T. J., Lyons, T. and Riboulleau, A.: Trace metals as paleoredox and paleoproductivity proxies: An update, Chem. Geol., 232, 12-32, doi:10.1016/j.chemgeo.2006.02.012, 2006.

Turgeon, S. C. and Creaser, R. A.: Cretaceous oceanic anoxic event 2 triggered by a massive magmatic episode, Nature, 454, 323326, doi:10.1038/nature07076, 2008.

Tyson, R. V.: Sedimentary organic matter: organic facies and palynofacies, Chapman \& Hall, 1995.
Tyson, R. V.: The "productivity versus preservation" controversy: cause, flaws, and resolution, in The Deposition of OrganicCarbon-Rich Sediments: Models, Mechanisms, and Consequences, edited by: Harris, N. B., 17-33, SEPM Special Publication No. 82, 2005.

van Bentum, E. C., Hetzel, A., Brumsack, H.-J., Forster, A., Reichart, G.-J., and Sinninghe Damsté, J. S.: Reconstruction of water column anoxia in the equatorial Atlantic during the Cenomanian-Turonian oceanic anoxic event using biomarker and trace metal proxies, Palaeogeogr. Palaeocl., 280, 489-498, doi:10.1016/j.palaeo.2009.07.003, 2009.

van Bentum, E. C., Reichart, G. J., Forster, A., and Sinninghe Damsté, J. S.: Latitudinal differences in the amplitude of the OAE-2 carbon isotopic excursion: $p \mathrm{CO}_{2}$ and paleo productivity, Biogeosciences, 9, 717-731, doi:10.5194/bg-9-717-2012, 2012.

Watts, B. and Ade, H.: NEXAFS imaging of synthetic organic materials, Mater. Today, 15, 148-157, 2012.

Williams, L. B., Canfield, B., Voglesonger, K. M., and Holloway, J. R.: Organic molecules formed in a "primordial womb," Geology, 33, 913-916, doi:10.1103/G21751.1, 2005. 